\title{
In vivo anti-plasmodial activities and toxic impacts of lime extract of a combination of Picralima nitida, Alstonia boonei and Gongronema latifolium in mice infected with Chloroquine-sensitive Plasmodium berghei.
}

\author{
Emmanuel T. Idowu', Henry C.N Ajaegbu², Ahmed I. Omotayo ${ }^{1}$, Oluwagbemiga O. Aina ${ }^{3}$, \\ Olubunmi A. Otubanjo ${ }^{1}$
}

1. Department of Zoology,University of Lagos,Akoka,Lagos,Nigeria

2. Nigeria Natural Medicine Development Agency, Federal Ministry of Science and Technology

3. Biochemistry Division, Nigerian Institute of Medical Research

\begin{abstract}
Background: Lime extracts of powdered combination of seeds of Picralima nitida, stem bark of Alstonia boonei and leaves of Gongronema latifolium is a common remedy used in the treatment of malaria in South Western Nigeria.

Objective: To determine the antiplasmodial activities of the combined herbal extracts and its impact on the haematological, hepatological and renological parameters in mice.

Methods: The 4-day suppressive and curative tests were used to assess the antiplasmodial activities of the extract in mice infected with chloroquine-sensitive Plasmodium berghei at concentration of $200 \mathrm{mg} / \mathrm{kg}, 400 \mathrm{mg} / \mathrm{kg}$ and $800 \mathrm{mg} / \mathrm{kg}$ body weight. The haematological parameters including red blood cells, white blood cells, packed cell volume and haemoglobin count were analysed with an auto analyser. The activities of alanine aminotransferase (ALT), aspartate aminotransferase (AST) and alkaline phosphatase (ALP) were determined, while urea, protein and creatinine were analysed by standard procedural methods.

Results: The 4-day suppressive test revealed that the test extract achieved percentage suppression of $39.0 \%, 41.6 \%$ and $54.68 \%$ for the $200 \mathrm{mg} / \mathrm{kg}, 400 \mathrm{mg} / \mathrm{kg}$ and $800 \mathrm{mg} / \mathrm{kg}$ concentration respectively. Additionally, the curative test achieved a high percentage suppression of $80.97 \%, 83.84 \%$ and $86.16 \%$ at the $200 \mathrm{mg} / \mathrm{kg}, 400 \mathrm{mg} / \mathrm{kg}$ and $800 \mathrm{mg} / \mathrm{kg}$ concentration respectively. The extracts did not induce significant change on haematological parameters $(\mathrm{P}>0.05)$, while significant elevation in the values of the ALT and AST $(\mathrm{P}<0.05)$ was observed and elevation of creatinine $(\mathrm{P}<0.05)$ at $800 \mathrm{mg} / \mathrm{kg}$.

Conclusions: The results support the traditional use of the herbal combination in the treatment of malaria, however the liver cells were impacted by the extracts in bioassay conducted with mice.

Keywords: In vivo anti-plasmodial lime extract, Picralima nitida, Alstonia boonei, Gongronema latifolium, mice infected with chloroquine-sensitive plasmodium berghei.

DOI: http://dx.doi.org/10.4314/ahs.v15i4.27

Cite as: Idown ET, Ajaegbu HCN, Omotayo AI, Aina OO, Otubanjo OA. In vivo anti-plasmodial activities and toxic impacts of lime extract of a combination of Picralima nitida, Alstonia boonei and Gongronema latifolium in mice infected with Chloroquine-sensitive Plasmodium berghei. Afri Health Sci. 2015;15(4):1262-70. bttp://dx.doi.org/10.4314/abs.v15i4.27
\end{abstract}

\section{Background}

Malaria is one of the leading public health problems in many countries of the world, especially in tropical and subtropical regions of the world. An estimated 3.4 billion people were at risk of malaria in $2012^{1}$. Nigeria accounts for a quarter of all malaria cases in the World Health Organization African region².
Corresponding author:
Emmanuel T. Idowu,
Department of Zoology,
University of Lagos,Akoka,Lagos,Nigeria
Email: etidowu@yahoo.com/
eidowu@unilag.edu.ng

Recently artemisinin has been widely used alone or in combination for malaria treatment. However, a major challenge of resistance to these drugs by the Plasmodium species has been a cardinal set back in the treatment of the disease. The rapid emergence and widespread of resistance to all currently available antimalarials coupled with the fact that, the chloroquine resistance transporter gene has also been associated with increased susceptibility to artemisinin, quinine and amodiaquine calls for the development of new potent antimalarials ${ }^{3}$.

The search for novel potent antiplasmodial drugs has led to numerous investigations into traditional medicinal plants already used by local residents of malaria endemic regions of Africa and Asia ${ }^{4-7}$. 
In preparation of herbal recipes for malaria therapy, a single plant or its combination with other plants could be used. The combination of these different plants were claimed to cure and alleviate several ailments and dysfunctions in the body associated with malaria and it has been speculated that the active ingredients of each plant in the preparation complemented one another in the fight against malaria parasite. Plant combination used in South Western Nigeria includes: Alstonia boonei (bark), Mangifera indica (bark, leaves), Psidium guajava (leaves), Carica papaya (leaves); Enantia Chlorantha (bark), Alstonia boonei (bark), Diospyros mespiliformis (bark); Ocimum gratissimum (Leaves), Anarcadium occidentale (foliage leaves), Lecaniodiscus cupanioides (foliage leaves), Curcuma longa (foliage leaves) and Citrus aurantifolia (foliage leaves) ${ }^{5}$.

The use of these traditional medicinal plants without specified accurate dosage and clear knowledge of the toxic impacts of their constituent compounds on body organs may be an impediment to the usage of the plants despite the acclaimed efficacy. Ethanolic extracts of Clerodendrum violaceum leaves considerably reversed the alterations caused by malaria infection in liver and kidney function enzymes and is relatively non-toxic but significantly increased the level of liver $\mathrm{ALT}^{8}$ and aqueous extracts of Phyllantus amarus does not adversely affect the weight and the haematological parameters of Plasmodium berghei infected mice ${ }^{9}$.

Previous findings have identified seeds of Picralima nitida ${ }^{10}$ and stem bark of Alstonia boonei as having antiplasmodial effects ${ }^{5}$, P. nitida leaves, roots, seeds and stem bark are also used by local traditional doctors for the treatment of fever, hypertension, jaundice and gastrointestinal disorders ${ }^{11}$.

Alstonia boonei is among the medicinal plants that have been widely used in recipes to treat malaria ${ }^{6,12}$. The stem bark of this plant has been found to be effective in the treatment of several diseases such as fever, painful micturition, insomnia, chronic diarrhea and has, rheumatic anti-inflammatory, antipyretic and analgesic properties $^{13-14}$.

Gongronema latifolium is widely employed in Nigeria for various medicinal and nutritional purposes ${ }^{15,16}$. Its hypoglycaemic, cardio-protective, hypolipidaemic, anti-inflammatory and antioxidative properties have been reported $^{17-18}$. In addition it has been reported to exhibit strong antiplasmodic and bactericidal activities ${ }^{19}$.
One of the locally available combinations of medicinal plants employed in the chemotherapy of malaria in South Western Nigeria is made from different parts of these three different medicinal plants, these include seeds of Picralima nitida, stem bark of Alstonia boonei, leaves of Gongronema latifolium soaked in Citrus aurantifolia (per com). Therefore, this study seeks to evaluate and establish the antiplasmodial activities as well as the suppressive and curative capacity of the combined herbal extracts and also determine its impacts on the haematological, hepatological and renalogical parameters in Plasmodium berghei infected mice.

\section{Methods \\ Plant materials and extraction}

The different part of the four medicinal plants namely the seeds of Picralima nitida, stem bark of Alstonia boonei, fresh leaves of Gongronema latifolium were collected during the month of September, 2013 in Awun Otta, OgunState, South West Nigeria. The identification and authentication was done by the Ethno-Survey Unit, Research and Training Department, Nigeria Natural Medicine Development Agency, Federal Ministry of Science and Technology, Lagos. Specimens of the plant species were also deposited at the same centre. All the specimen were cleaned with water and seeds of P. nitida were air-dried for two weeks, fresh leaves of G. latifolium were air dried for five days, while stem bark of A. boonei were cut into small sizes and air dried for two weeks. Fresh juice from the fruits of Citrus aurantifolium (lime) were collected from the matured fruits after cutting and hand pressed to obtain the liquid which was then filtered to remove the seeds from the solvent. All the three different plant parts were grounded to powder differently, and stored in different well sealed containers prior to extraction which was carried out at the Biochemistry Division laboratory, Nigerian Institute of Medical Research (NIMR), Lagos, Nigeria.

The plant extracts were mixed together in a ratio of 2 : 2: $1 ; 4.2$ grams of P. nitida and A. boonei with 2.1 grams of G. latifolium mixed as a combined extract to form a total of 10.5 grams which is equivalent of one table spoon full and mixed in a solution of $175 \mathrm{ml}$ lime juice. The aqueous extract was kept in a well-sealed plastic container and stored in a refrigerator for three days to allow full extraction of the active ingredients from the medicinal plants. On day 3, the preparation was filter-sterilized by passage through a $45 \mathrm{~m}$ Millipore membrane filter (St. Quentine, France) and the filtrate was utilized for the experiment. 


\section{Drugs preparation}

0.5 grams or tablets of Chloroquine phosphate, CQ (Emezor Pharma, Nigeria) was dissolved in $10 \mathrm{ml}$ Phosphate buffered saline (PBS) to final doses of $5 \mathrm{mg} / \mathrm{kg}$ body weight. These served as positive control.

\section{Animals}

Fifty pure strains and adult Swiss albino mice with an average weight of $21 \mathrm{~g}$ were obtained from the Animal house, NIMR, Yaba, Lagos. The animals were observed under 12 hours light/dark cycles in clean and well maintained cages in the Biochemistry laboratory of NIMR. The rats were fed with mice pellets diet (Ladokun Farms, Ibadan Nigeria) and water ad libitium for one week so as to acclimatize to room temperature of $29^{\circ} \mathrm{C}$.

\section{Preparation of parasites and innoculum}

A Chloroquine-sensitive Plasmodium berghei parasite which was obtained from the Biochemistry Division, NIMR, Lagos was used for the study. Test mice were infected with blood samples from the donor mice obtained by ocular puncture, using a heparinized sterile capillary tube. The infected blood was diluted with phosphate buffer saline to enable innoculum of $0.1 \mathrm{ml}$ for each mouse which contains the required number of parasitized red blood cell $\left(10^{6}\right)$. The red blood cells (RBC) per unit volume was calculated based on the innoculum size. The normal number of parasitized red blood cells was calculated by multiplying the percent of parasitemia with the number of red blood cells. The inoculated mice were then randomised into cages $\mathrm{A}, \mathrm{B}$, C, D and E, with each cage having 5 mice each.

\section{Antiplasmodial studies of plant extracts Suppressive treatment}

The four day suppressive test ${ }^{20}$ was adopted for the study. Mice of both sexes weighing (16-26g) which had been intraperitoneally infected with 106 erythrocytes in $0.1 \mathrm{ml}$ phosphate buffer saline were randomised into five groups, A, B, C, D and E with each group having five (5) animals each. Treatment of animals started after 2 hours on Day 0. Group A and B served as the control groups, while group $\mathrm{C}, \mathrm{D}$ and $\mathrm{E}$ served as the test groups. Group A animals served as the negative control group. Group B animals were administered with $30 \mathrm{mg} /$ $\mathrm{kg}$ of chloroquine diphosphate which serves as the positive control group. In groups C, D and E, the infected animals were treated for four (4) days with doses of selected 200, 400 and $800 \mathrm{mg} / \mathrm{kg}$ body weight with the filtered extracts of the herbal combination through oral route using an oral canula. On day 4, thin films were made from the tail blood of each mouse under aseptic conditions from 07:00 to 09:00am. The blood smears were prepared by spreading the blood on a clean glass slide at angle 45 degrees, fixed with methanol, stained with 3\% Giemsa stain for 45 minutes and examined with microscope under the oil immersion objective to determine the percentage parasiteamia microscopically (Olympus CX, Japan). This is necessary as to monitor the level of percentage suppression which was then calculated. Death or mortality within 24 hours of the herbal extraction administration was considered toxic to the animal.

The suppression of parasitaemia in relation to the control was calculated using the recommended formula:

Average $(\mathrm{Av}) \%$ suppression=

$\mathrm{Av} \%$ parasitaemia in control $-\mathrm{Av} \%$ parasitaemia in test $\mathrm{x} 100$

$$
\mathrm{Av}^{\mathrm{O}} \% \text { parasitaemia in control }
$$

\section{Curative treatment}

The procedure of Ryles and Peters was adopted for this study $^{21}$. On day 0, twenty five (25) Swiss albino mice were grouped into five with each group having five animals per cage based on body weight after standard intraperitoneal inoculation of $1 \times 10^{6}$ Plasmodium berghei infected red blood cell. All mice were inoculated with $10^{6}$ parasitized red blood cells in $0.1 \mathrm{ml}$ of phosphate buffer saline. Group A with the least body weight were considered the negative control group and given distilled water. Group B animals which were selected as the positive control group were given a curative dose of $30 \mathrm{mg} / \mathrm{kg}$ of Chloroquine for three (3) days daily through oral canular. The other test groups, C, D and $\mathrm{E}$ were administered with the selected doses concentration of $200 \mathrm{mg}, 400 \mathrm{mg}$ and $800 \mathrm{mg} / \mathrm{kg}$ body weight $(0.1 \mathrm{ml}, 0.2 \mathrm{ml}$ and $0.4 \mathrm{ml})$ of the prepared herbal extract for five days. Preparation of thick blood film from the tail blood of the animals commenced on the third day post inoculation, the herbal extract treatment administration started on the same day and continued till day seven. Accordingly, the parasite density was calculated by counting the number of parasite against 200 white blood cells (WBC) and multiplied by 8000 .

\section{Determination of haematological and biochemical parameters}

On the fifth day of post treatment, three mice each were removed from each group or cage, $5 \mathrm{ml}$ of blood 
was taken from the left eye (ocular) side of the mice with micro haematocrit tubes through a $5 \mathrm{ml}$ pipe tubes. Two (2) mls of blood was used for the haematological analysis. The haematological parameters analysed were Haeamoglobin count $(\mathrm{Hb})$, White Blood Cell Count (WBC), Red Blood Cell Count (RBC) and Packed Cell Volume (PCV). The blood was analysed with the aid of an auto analyser (Minray Model BC 3200).

Three (3) mls of the blood was used for biochemical analysis. A sample collected from each mouse was used for quantitative determination of protein, alanine aminotransferase (ALT), aspartate aminotransferase (AST) and alkaline phosphatase (ALP), urea and creatinine. ALT and AST levels were measured with commercially available standard blood ALT and AST kits by Randox Reitman and Frankel ALT and AST level 2 controls (Cat. No. SC2643) respectively. The method of Young ${ }^{22}$ was employed in the ALP analysis. The plasma urea level was measured with commercially available standard blood urea kit by Biolabo, South Africa. The plasma creatinine level was measured with commercially available standard blood creatinine kit by standard protocol for photometric determination of creatinine based on Jaffe kinetic method ${ }^{23}$. The Biuret method was used for the measurement of protein level, while the Sulfanilic acid method was employed in the measure of total bilirubin level ${ }^{24}$.

\section{Results}

The result of the study showed that the extract did not cause mortality within $24 \mathrm{hrs}$ at all doses, as death was only witnessed in the negative control on the third day of treatment. All the mice were physically active, except in the negative control. Gross physical and behavioural observations of the experimental mice also revealed no visible signs of acute toxicity like trembling, loss of hair, loss of appetite and reduction in agility.

\section{Suppression of parasitaemia}

Significant reduction of parasitaemia $(\mathrm{P}<0.05)$ was observed in all groups of mice treated with the herbal extract when compared to the negative control. The effects of these combined herbal extract was significant when compared with the negative control, while Chloroquine $(30 \mathrm{mg} / \mathrm{kg}$ ) caused $100 \%$ suppression. The percentage suppression in the group of animals treated with $200 \mathrm{mg} / \mathrm{kg}$ was $39.0 \%$, while the highest suppression $(54.68 \%)$ was recorded in the group treated with the highest dose, that is $800 \mathrm{mg} / \mathrm{kg}$ (Table1). Reduction of the parasitaemia was dose dependent as suppression increases with increase in concentration of the test extract.

Table 1: Suppressive assay of the combination of powdered seed of Picralima nitida, stem bark of Alstonia boonei and leaves of Gongronema latifolium in Plasmodium berghei infected mice.

\begin{tabular}{lllll}
\hline Treatment & Groups & Dose $(\mathrm{mg} / \mathrm{kg})$ & $\begin{array}{l}\text { Parasitaemia count in } \\
\text { thousand(Mean } \\
\text { S.D) }\end{array}$ & $\begin{array}{l}\text { \% Supression in } \\
\text { Parasitaemia }\end{array}$ \\
\hline Control -ve & $\mathrm{A}$ & $?$ & $11.54 \pm 2.67$ & - \\
\cline { 2 - 5 } Control +ve & $\mathrm{B}$ & 30 & - & 100 \\
\cline { 2 - 5 } Lime Extract & $\mathrm{C}$ & 200 & & \\
& $\mathrm{D}$ & 400 & $7.04 \pm 2.81$ & 39.0 \\
& $\mathrm{E}$ & 800 & $6.74 \pm 2.08$ & 41.6 \\
& & $5.23 \pm 1.55$ & $\mathbf{5 4 . 6 8}$ \\
\hline
\end{tabular}

\section{Clearance of parasitaemia}

The results of the study indicated that the test extract displayed a very potent antiplasmodial activity against $\mathrm{P}$. berghei malaria parasite in vivo when given at doses of 200, 400 and $800 \mathrm{mg} / \mathrm{kg}$. Although, the extract failed to totally clear the parasites, however a high level of clear- ance was achieved on the fourth day of post infection. The average parasitaemia count (in thousands) on the fourth day of post infection was $3.5 \pm 0.7,1.9 \pm 8.0$, and $1.2 \pm 0.4$ (Table 2). Percentage parasitaemia clearance was $80.97 \%, 83.84 \%$ and $86.16 \%$ for the 200,400 and $800 \mathrm{mg} / \mathrm{kg}$ body weight respectively, (Figure 1) while that of Chloroquine was $100 \%$. 
Table 2: Curative assay (treatment) of the combination of powdered seeds of Picralima nitida, stem bark of Alstonia boonei and leaves of Gongronema latifolium in Plasmodium berghei infected mice.

\begin{tabular}{|c|c|c|c|c|c|c|c|}
\hline \multirow{2}{*}{\multicolumn{2}{|c|}{$\begin{array}{l}\text { Treatment } \\
\text { Dose }\end{array}$}} & \multirow[t]{2}{*}{ Group } & \multicolumn{5}{|c|}{ Parasitaemia count for the Treatment days (in thousands) } \\
\hline & & & Day 0 & Day 1 & Day 2 & Day 3 & Day 4 \\
\hline \multicolumn{8}{|c|}{$(\mathrm{mg} / \mathrm{kg})$} \\
\hline \multirow[t]{2}{*}{ Control } & & $?$ & $56.06 \pm 55.9$ & $54.9 \pm 24.5$ & $50.9 \pm 14.5$ & $55.2 \pm 16.9$ & $55.7 \pm 11.3$ \\
\hline & $+\mathrm{ve}$ & 30 & $68.92 \pm$ & $42.31 \pm 11.2$ & 0 & 0 & 0 \\
\hline \multirow{3}{*}{ CQ } & B & & 23.1 & - & - & - & - \\
\hline & $\mathrm{C}$ & 200 & $45.3 \pm 11.9$ & $38.0 \pm 6.2$ & $23.6 \pm 5.4$ & $17.2 \pm 2.0$ & $10.6 \pm 8.0$ \\
\hline & $\mathrm{D}$ & 400 & $36.4 \pm 12.9$ & $30.6 \pm 6.8$ & $21.9 \pm 3.8$ & $16.8 \pm 3.6$ & $9.0 \pm 0.7$ \\
\hline Extract & E & 800 & $38.6 \pm 11.5$ & $31.4 \pm 7.9$ & $16.9 \pm 6.2$ & $11.1 \pm 2.7$ & $7.7 \pm 0.4$ \\
\hline
\end{tabular}

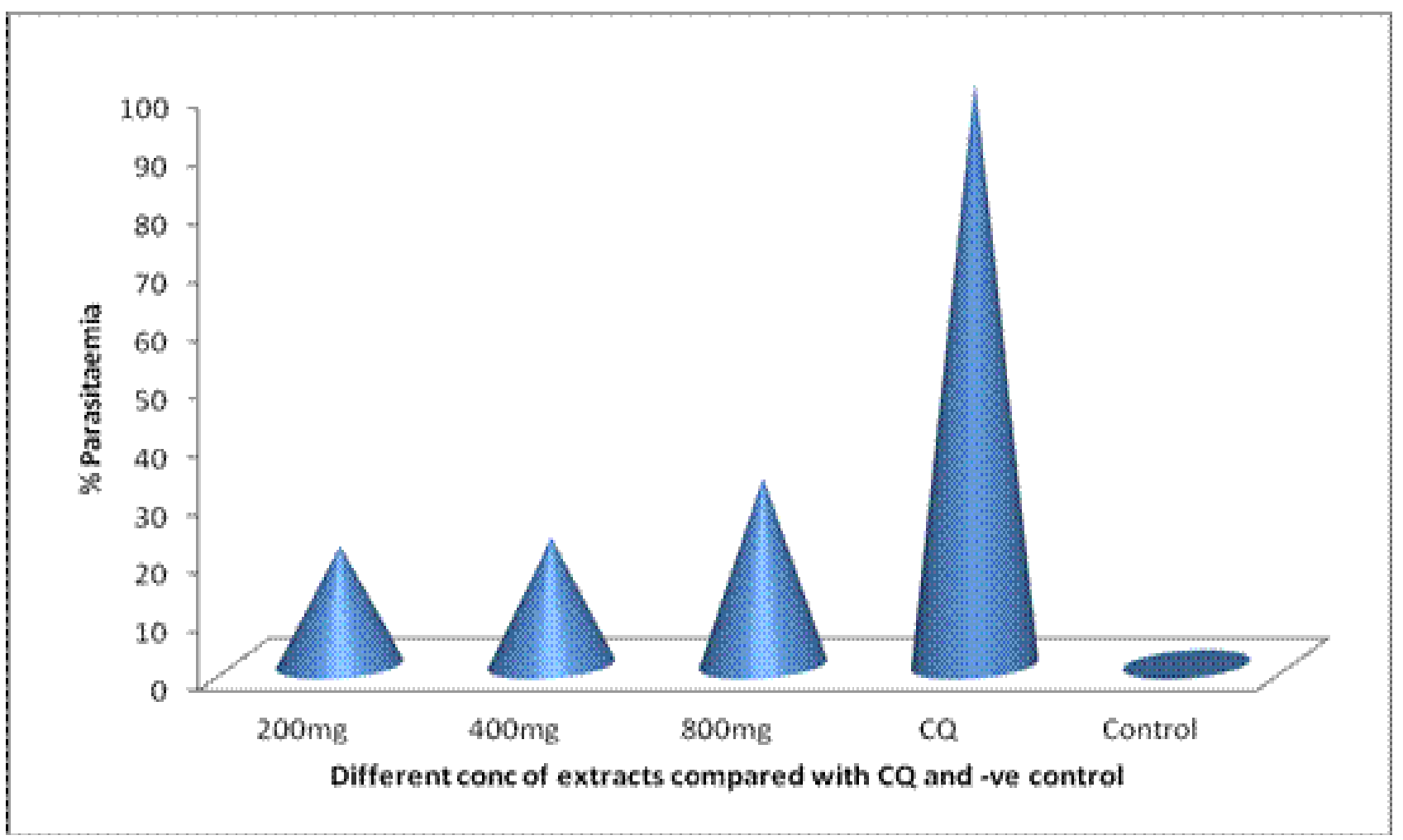

Figure 1: Percentage Suppression of the combination of powdered seed of Picralima nitida, stem bark of Alstonia boonei and leaves of Gongronema latifolium in Plasmodium berghei infected mice

Haematological and biochemical parameters

The heamatological examination revealed that there was significant reduction $(\mathrm{P}>0.05)$ in $\mathrm{RBCs}$ at all treatment doses. The WBC was only significant when compared with the positive control at $800 \mathrm{mg} / \mathrm{kg}$. There was no observed difference $(\mathrm{P}<0.05)$ in the $\mathrm{Hb}$ and $\mathrm{PCV}$ levels of all the treated groups when compared to the negative control (Table 3). 
Table 3: Haematological evaluation of controls and Plasmodium berghei infected mice treated with combination of powdered seed of Picralima nitida, stem bark of Alstonia boonei and leaves of Gongronema latifolium.

\begin{tabular}{llllll}
\hline Parameters & Control -ve & Control $+\mathrm{ve}$ & $200 \mathrm{mg} / \mathrm{kg}$ & $400 \mathrm{mg} / \mathrm{kg}$ & $800 \mathrm{mg} / \mathrm{kg}$ \\
\hline $\mathrm{RBC}$ & $3.31 \pm 0.21$ & $5.27 \pm 0.31$ & $3.17 \pm 0.21^{*}$ & $3.43 \pm 0.59^{*}$ & $3.97 \pm 0.50^{*}$ \\
$\mathrm{WBC}$ & $8000 \pm 721.0$ & $8800 \pm 1216.55$ & $12733 \pm 1026.0$ & $7600 \pm 600$ & $5133.33 \pm 901.85^{*}$ \\
$\mathrm{PCV}$ & $30.67 \pm 1.52$ & $38.33 \pm 2.52$ & $27 \pm 3.0$ & $28.67 \pm 4.4$ & $32 \pm 2.65$ \\
$\mathrm{Hb}$ & $10.14 \pm 0.47$ & $12.68 \pm 0.76$ & $8.98 \pm 1.03$ & $9.49 \pm 1.37$ & $10.61 \pm 0.92$ \\
\hline
\end{tabular}

$\mathrm{RBC}=$ Red blood cell, $\mathrm{WBC}=$ White blood cell, $\mathrm{PCV}=$ Packed cell volume, $\mathrm{Hb}=$ Haemoglobin,

*=Significant difference

The biochemical examination revealed significant increase in the levels of AST, ALT and Urea ( $\mathrm{P}>0.05)$, but no significant increase in the levels of ALP and pro- tein $(\mathrm{P}<0.05)$ for all the doses of the treatment groups. Creatinine level only showed significant difference at $800 \mathrm{mg} / \mathrm{kg}$ when compared to the control groups (Table 4).

Table 4: Biochemical evaluation of controls and Plasmodium berghei infected mice treated with combination of powdered seed of Picralima nitida, stem bark of Alstonia boonei and leaves of Gongronema latifolium.

\begin{tabular}{llllll}
\hline Parameters & Control -ve & Control +ve & $200 \mathrm{mg} / \mathrm{kg}$ & $400 \mathrm{mg} / \mathrm{kg}$ & $800 \mathrm{mg} / \mathrm{kg}$ \\
\hline AST $(\mu / \mathrm{L})$ & $147.5 \pm 5.5$ & $117 \pm 1.00$ & $160 \pm 1.00^{*}$ & $182.5 \pm 3.5^{*}$ & $184 \pm 7.0^{*}$ \\
ALT $(\mu / \mathrm{L})$ & $37 \pm 0.00$ & $36 \pm 2.00$ & $47 \pm 1.00^{*}$ & $45.5 \pm 1.5^{*}$ & $49.5 \pm 0.5^{*}$ \\
ALP $(\mu / \mathrm{L})$ & $63.48 \pm 8.28$ & $115.92 \pm 5.52$ & $168.36 \pm 13.8$ & $182.16 \pm 27.6$ & $124.2 \pm 13.8$ \\
Urea $(\mathrm{mg} / \mathrm{dl})$ & $56.97 \pm 2.42$ & $77.58 \pm 2.43$ & $85.45 \pm 0.61^{*}$ & $86.66 \pm 1.82^{*}$ & $92.13 \pm 3.64^{*}$ \\
Creatinine & $1.09 \pm 0.03$ & $0.76 \pm 0.11$ & $0.8 \pm 0.02$ & $1.07 \pm 0.01$ & $1.46 \pm 0.03^{*}$ \\
$(\mu \mathrm{mol} / \mathrm{L})$ & & & & & \\
Protein $(\mathrm{g} / \mathrm{L})$ & $30.9 \pm 0.40$ & $34.75 \pm 2.39$ & $33.09 \pm 2.33$ & $36.67 \pm 1.4$ & $35.54 \pm 0.4$ \\
\hline
\end{tabular}

$\mathrm{AST}=$ Aspartate transaminase, $\mathrm{ALT}=\mathrm{Alanine}$ transaminase, $\mathrm{ALP}=\mathrm{Alanine}$ Phosphatase

$*=$ Significant difference

\section{Discussion}

The emergence of Plasmodium falciparum multi-drug resistant malaria and drug resistance to artemisinin-derivatives and to other drug combination therapies makes the development of new potent antimalarial drugs imperative. Traditional medicinal plants have proved to be rich sources of new drugs coupled with the fact that antimalarial drugs in use presently were either obtained directly from plants or developed using chemical structures of plant-derived compound as templates. The feasibility of discovering new potent antimalarials from traditional medicinal plants is very promising. 
This study demonstrates the in vivo antiplasmodial activities of lime extract of a combination of powdered seeds of P. nitida, stem bark of A. boonei and fresh leaves of G. Latifolia. Four day chemosuppresive test showed that the extract achieved moderate suppression of the Plasmodium parasite in mice infected with P. berghei. Chemosuppression achieved in this study was dose dependent with chemosuppression rate of $54.68 \%$ at the highest dose $(800 \mathrm{mg} / \mathrm{kg})$. However, the percentage suppression achieved at $400 \mathrm{mg} / \mathrm{kg}$ dosage was lower than the percentage suppression achieved by the ethanolic extract of A. boonei alone as reported by some workers ${ }^{25}$. The low chemosuppression rate may be due to the antagonistic property of some active constituents of the plants or due to the difference in the effectiveness of the medium of extract.

The 4-day curative test revealed that the extract has a considerable high antiplasmodial effect. The curative effect was also dose dependent, but with a very small change with increase in dosage. The curative effect of the combined extract at $400 \mathrm{mg} / \mathrm{kg}$ body weight $(83.84 \%)$ was in the same range with that of $\mathrm{A}$. boonei extracts used alone $(81.36 \%)^{25}$. This is in line with previous findings that have confirmed the antimalarial effect of the three individual plants ${ }^{6,25}$. The antimalarial activity of the extracts could be attributed to the presence of some phytochemicals like alkaloids, tannins, saponins, flavonoids and terpenes present in the three plants used in the study. Specifically, the parasitaemia suppression effect of the extract may be attributed to the presence of alkaloids ${ }^{26}$.

An assessment of the impact of the extract on the haematological parameters showed marked difference $(\mathrm{p}<0.05)$ in the RBCs and WBCs $(\mathrm{mg} / \mathrm{kg})$ when compared with the positive control, but no difference when compared with the negative control. The RBC count increased with increase in the dose. It can be deduced that the significant reduction is not due to the impact of the extracts, but probably to the impact of the parasiteamia as reflected in the similarity in result for the negative control and the experimental mice. This could be easily explained with the fact that Plasmodium is known to colonise and lead to reduction in the RBCs and the reduction in WBCs which is similar to earlier ${ }^{38}$, this was probably due to the fact that most of the WBCs have been deployed and used up in the immune response of the body to the introduction of the parasitemia. Additionally, there was no significant change in the PCV and heamoglobin levels of the test groups. This is line with earlier findings on some other traditional plants ${ }^{8}$.

The AST and ALT level increased with increase in the dose of the extract. There was significant difference in the value of the experimental animals when compared with the two controls, providing sufficient evidence that the impact was due to the extract. This has also been reported in earlier findings on other traditional medicinal plants such as Chrozophora senegalenesis ${ }^{28}$ and ethanolic extract of Magnifera indica ${ }^{29}$. The level of the ALP showed no difference in all the experimental animals, suggesting that the leakage in AST and ALT was from the liver and not bile duct. Considering the observation in the three parameters, it can be adduced that the extract had an impact on the liver, thereby allowing a leakage of AST and ALT into the blood stream.

The plasma protein showed no significant difference. However, urea level significantly increased with increase in dosage, while creatinine showed significant difference $(\mathrm{p}<0.05)$ only at the highest dose $(800 \mathrm{mg} / \mathrm{kg})$. Protein level is a good indicator of renal malfunction, but also elevated levels of creatinine and urea are sound indicators of deficiency in renal function ${ }^{30}$ This suggests a mild damage to the kidney which may become acute at higher doses and with prolonged use. The damage is assumed to be mild because urea levels do not reflect the performance of the kidneys like creatinine. This is because urea production is also affected by dehydration, food intake and tissue catabolism ${ }^{30}$. Histological examination may however be used to clearly establish renal malfunction.

The increase in the incidence of resistance to current antimalarials coupled with the spread of fake antimalarials makes the development of traditional medicinal plant the most probable short term sustainable solution to malaria treatment. Locally used medicinal plants can be fully assessed to establish their potency and also determine their prospect as sources of new antimalarial agents. Further work is suggested to characterize the active ingredients and to establish a full risk profile of the combined plant extracts. 


\section{References}

1. World Malaria Report. Geneva: World Health Organization 2013. Available from http://www.who.int/ malaria/wmr2013/malaria2013

2. WHO. World Malaria Report 2008. World Health Organization, Geneva, 2008; 99-101 PubMed .

3. Wang P, Read M, Sims PF, Hyde JE. Sulfadoxine resistance in the human malaria parasite Plasmodium falciparum is determined by mutations in dihydropteroate synthetase and an additional factor associated with folate utilization. Molecular Microbiology 1997; 23: 979986 DOI: 10.1046/J.1365-2958.1997.2821646.X.

4. Wells TN, Alonso PL, Gutteridge WE. New medicines to improve control and contribute to the eradication of malaria. Nature Reviews Drug Discovery 2009; 8: 879-890. DOI: 10.1038/NRD2972.

5. Odugbemi TO, Akinsulire OR, Aibinu IE, Fabe$\mathrm{ku}, \mathrm{PO}$. Medicinal plants useful for malaria therapy in Okeigbo, Ondo State, Southwest Nigeria. African Journal of Traditional Complementary and Alternative Medicine 2007; 4:191-198.

6. Idowu OA, Soniran OT, Ajana O, Aworinde DO. Ethnobotanical survey of antimalarial plants used in Ogun State, Southwest Nigeria. African Journal of Pharmacy and Pharmacology 2010; 4:055-060.

7. Ibrahim HA, Imam IA, Bello AM, Umar U, Muhammad S, Abdullahi SA.. The Potential of Nigerian Medicinal Plants as Antimalarial Agent: A Review. International Journal of Science and Technology 2012; 2(8):600-605. 8. Adebayo JO, Zailani AH, Balogun EA. Effects of Clerodendrum violaceum Leaf Extract on Some Liver Function Indices in Plasmodium berghei-Infected Mice. Research Journal of Parasitology 2009; 4(1):12.

9. Kabiru AY, Abdulkadir GA, Timothy A, Bello UM, Makun HA, Amah DJ, Ogbadoyi EO. Evaluation of Haematological Changes in Plasmodium-berghei-infected Mice Administered with Aqueous Extract of Phyllantus amarus. Pakistan Journal of Biological Sciences 2013; 16(11): 510

10. Okokon JE, Antia BS, Igboasoiyi AC, Essien EE, Mbagwu HO. Evaluation of antiplasmodial activity of ethanolic seed extract of Picralima nitida. Journal of Ethnopharmacology 2007; 111:464-467. DOI:10.1016/J. JEP.2006.12.016

11. Etukudo I. Ethnobotany. Conventional and Traditional uses of plants. 2003; Vol. 1. The Verdict Press, Uyo, p. 191.

12. Titanji VPK, Zofou D, Ngemenya MN. The antimalarial potential of medicinal plants used for the treatment of malaria in Cameroonian folk medicine. African
Journal of Traditional, Complimentary and Alternative Medicine 2008; 5:302-321.

13. Olajide OA, Awe SO, Mikinde JM, Ekhler AI, Olusola A, Morebise O, Okpako DT. Studies on the anti-inflammatory, antipyretic and analgesic properties of Alstonia boonei stem bark. Journal of Ethnopharmacology 2000; 71:179-186. DOI:10.1016/S0378-8741(99)002007

14. Odeku OA, Adegoke OA, Majekodunmi SO. Formulation of the extract of the stem bark of Alstonia boonei as tablet dosage form. Tropical Journal of Pharmacentical Research 2008; 7:987-994.

15. Ugochukwu NH, Babady NE, Cobourne M, Gasset SR. The effect of Gongronema latifolium leaf extract on serum lipid profile and oxidative stress of hepatocytes of diabetic rats. Journal of Biosciences 2003; 28:1-5. 16. Morebise O, Fafunso MA, Makinde JM, Olajide $\mathrm{O}$, Awe EO. Anti-inflammatory property of the leaves of Gongronema latifolium. Phytotherapy Research 2002; 16(1): 75-77. DOI: $10.1002 /$ ptr.784

17. Edet EE, Akpanabiatu MI, Eno AE, Umoh IB, Itam EH. Effect of Gongronema latifolium crude leaf extract on some cardiac enzymes of alloxan-induced diabetic rats. Africa Journal of Biochemical Research 2009; 3(11): 366-369.

18. Ogundipe OO, Moody JO, Akinyemi TO, Raman A. Hypoglycemic potentials of methanolic extracts of selected plant foods in alloxanized mice. Plant Foods for Human Nutrition 2003; 58(3): 1-7. DOI:10.1023/ B:QUAL.0000040321.56831.c4

19. Osunkwo UA, Akuodor GC, Idris-Usman MS, Mbah CC, Megwas UA, Akpan JL, Ugwu TC, Okoroafor DO, Studies on anti-ulcer, analgesic and antipyretic properties of the ethanolic leaf extract of Gongronema latifolium in rodents. African Journal of Biotechnology 2010; 9(15):2316-2321. DOI: 10.5897/AJB2010.0003036

20. Peters W. Drug resistance in Plasmodium berghei Venke and Lips I. Chloroquine resistance. Experimental Parasitology 196548; 17(1): 80-897.

21. Ryley JF, Peters W. The antimalarial activity of some quinone esters. Annals of Tropical Medicine and Parasitology 1970; 864: 209-222.

22. Young DS, Pestaner LC, Gibberman V. Effects of drugs on clinical laboratory tests. Clinical Chemistry 1975; 21(5):1D-432D.

23. Ferry N, Caillette A, Goudable J, Denicola C, Pozet $\mathrm{N}$. Creatinine determination in peritoneal dialysis what method should be used? Nephrology Dialysis Transplant. 1996; 11: 2285-2287. 
24. Tietz NW, Shuey DF. Lipase in serum the elusive enzyme: an overview. Clinical Chemistry 1993; 39:746756.

25. Iyiola OA, Tijani AY, Lateef KM. Antimalarial activity of ethanolic stem bark extract of Alstonia boonei in mice. Asian Journal of Biological Sciences 2011; 4:235-243. DOI: 10.3923/ajbs.2011.235.243

26. Adebayo JO, Krettli AU. Potential antimalarials from Nigerian plants: A review. Journal of Ethnopharmacology 2011; 133: 289-302. DOI: 10.1016/J.JEP.2010.11.024 27. Ebiloma G, Amlabu E, Atanu FO, Amlabu W, Aminu Rhoda O. Effect of the aqueous extracts of Alstonia boonei on the haematological profiles of mice experimentally infected with the chloroquine-sensitive strain of Plasmodium berghei NK-65. Hematologia 2012; 1:11-18.

28. Ali AJ, Usman TA, Martins NE. In-vivo antimalarial and toxicological evaluation of Chrozophora senegalensis A. Juss (euphorbiaceae) extracts. Journal of Applied Pharmaceutical Science 2011; 1(10):90-94.

29. Ogbe RJ, Adenkola AY, Anefu E. Aqueous Ethanolic Extract of Mangifera indica Stem Bark Effect on the Biochemical and Haematological Parameters of Albino Rats. Archives of Applied Science Research 2012; 4(4):1618-1622.

30. Ekeanyanwu RC, Ogu GI. Assessment of renal function of Nigerian children infected with Plasmodium falciparum. International Journal of Medicine and Medical Sciences 2010; 2(9):251-255 